\title{
BETHANY BEYOND THE JORDAN (John 1:28) TOPOGRAPHY, THEOLOGY AND HISTORY IN THE FOURTH GOSPEL
}

\author{
Rainer Riesner \\ For Bargil Pixner OSB on his 65th Birthday
}

\section{INTRODUCTION}

One of my friends, who has a most noteworthy biography, is Bargil Pixner. ${ }^{1} \mathrm{He}$ was born in the South Tyrol, and as a young German soldier opposed to Hitler's National Socialism he almost paid with his life. After the War a political career was open to him in his native land, but he became a missionary and for many years he was, among other things, the leader of a leprosy station in the Philippines. Since 1968 he has lived in Israel and belongs to the Benedictine Dormition Abbey on Mount Zion in Jerusalem. He has two main concerns in his life: first, he strives to bring about unity among Christians, and hopes to achieve this preeminently through corporate prayer and the study of the Scriptures; secondly, he has dedicated himself to the investigation of biblical topography and archaeology. In this area his most important contribution is probably the claim that in New Testament tímes the Essene Quarter was situated on Mt Zion, that is on the southwestern hill of old Jerusalem. ${ }^{2}$

The stimulus for the following exposition I owe to Bargil Pixner. The interpretation of the Johannine topographical designation 'Bethany beyond the Jordan' which I advocate here, was his own independent discovery. Later on, as a matter of fact,

1 Biographical sketches appear in Jerusalem Post 4. 11. 1983 and H. Shanks (ed.), Who's Who in Biblical Studies and Archaeology (Washington, BAS 1986) 178.

2 'An Essene Quarter on Mount Zion?', Studia Hierosolymitana I: Studi archaeologici [Bellarmino Bagatti Festschrift ], (Studium Biblicum Franciscanum Collectio major 22; Jerusalem, Franciscan Printing Press 1976) 245-84; 'Das Essenerquartier in Jerusalem und dessen Einfluß auf die Urkirche', Das Heilige Land 113/2-3 (1981) 3-14; 'Unravelling the Copper Scroll Code: A Study on the Topography of 3Q15', Revue de Qumran 11 (1983) 323-67. Cf. also R. Riesner, 'Essener und Urkirche in Jerusalem', BiKi 40 (1985) 64-76. 
30

TYNDALE BULLETIN 38 (1987)

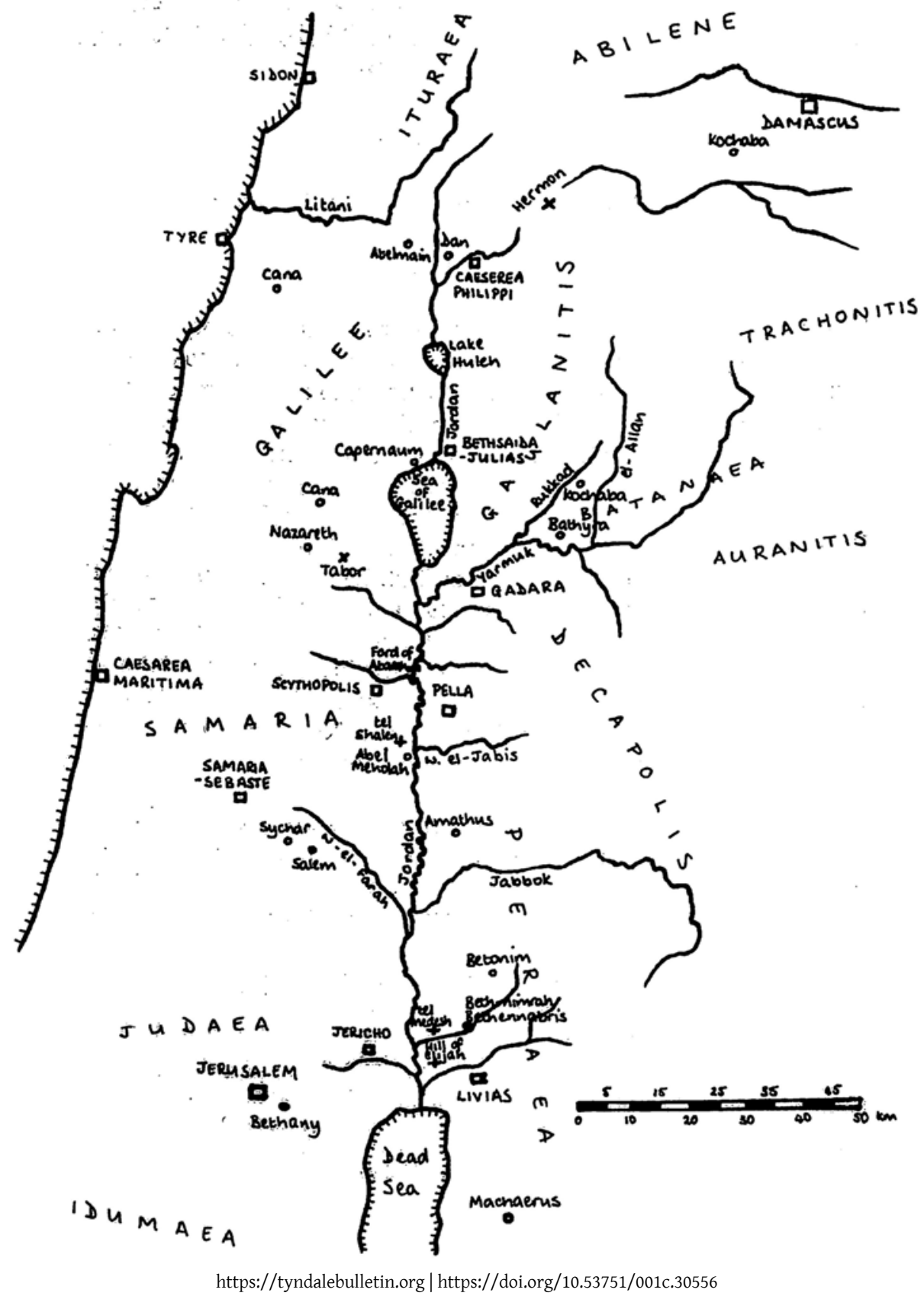


we saw that already in 1877 a famous topographer of the Holy Land, Claude R. Conder, had advocated the same view. On the other hand Captain Conder does not seem to have known that there was an allusion to this interpretation as early as $\mathbf{1 6 5 8}$ by another Englishman, John Lightfoot, in the Horae Hebraicae et Talmudicae. Perhaps we can only make 'new' discoveries in New Testament exegesis because in the meantime we have forgotten the history of the investigation of the New Testament at least before the middle of the last century. Over against this particular scepticism I hope, however, to be able to formulate some fresh observations which may be helpful for understanding the characteristics of John's Gospel.

My interest in the old topographical riddle 'Bethany beyond the Jordan' was awakened in 1982 during an excursion with Bargil Pixner to Tel Salem, some $12 \mathrm{~km}$ south of Beth Shean, the old Scythopolis. The earliest tradition we have ${ }^{3}$ is probably

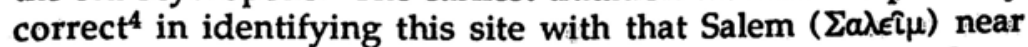
which, according to the Fourth Gospel, was one of the places where John the Baptist baptized (Jn 3:23). On this excursion we realized, as on a number of previous occasions, that while one can certainly discover connections between topography and history from a map, these connections become really striking when one actually stands on the site itself.

Two things were impressed upon our minds. First, not further than a half hour's walk away from Tel Salem lay Abel Mehulah, ${ }^{5}$ where Elijah anointed Elisha as his successor (1 Ki 19:16-21). Was it intentional that John the Baptist baptized in this region, especially since he appeared - at least according to the Synoptists (Mt 11:14; 17:11-13 // Mk 9:12-13; Lk 1:17) - as the eschatological Elijah? ${ }^{6}$ Secondly, looking across the Jordan from

3 Egeria, Peregrinatio 13.2 - 15.6 (P. Maraval [ed.], Égérie: Journal de voyage [SC 296; Paris, du Cerf 1982] 183-90); Eusebius, Onomastikon 40.1-4 (E. Klostermann [ed.], Das Onomastikon der biblischen Ortsnamen. Eusebius Werke [GCS III/1; Leipzig, J. C. Hinrichs 1904] 40).

${ }^{4}$ Cf. C. Kopp, The Holy Places of the Gospels (ET; Edinburgh - London, Nelson n.d.) 129-32; B. Manzano, 'Les sources d'Aenon, près de Salim, où Jean baptisait', Terre Sainte 5-6 (1987) 124-30.

${ }^{5}$ A valuable map for identifying the place names discussed below is E. Höhne, Palästina. Historisch-archäologische Karte (Göttingen, Vandenhoeck \& Ruprechí 1981).

${ }^{6} \mathrm{Cf} . \mathrm{M}$. Hengel, The Charismatic Leader and His Followers (ET; Edinburgh, T \& T Clark 1981) 35-7; and now, R. Macina, 'Jean le Baptiste était-il Elie? Examen de 
this position one sees very clearly the valley of Pella, only about a two-hour journey on foot. Was there a connection between the work of the Baptist in this region and the flight of the Jewish Christian Church before the commencement of the siege of Jerusalem to that part of northern Transjordan, which Eusebius relates (HE III. 5. 3)?

The starting point for our present investigation appears to have been chosen very narrowly - a single verse of John's Gospel, or more precisely, only the name of a place. Yet I myself was surprised at the avenues along which this investigation of John

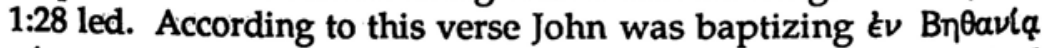
$\pi \in$ pav rov 'Iopsávov. We have here the first topographical designation connected with events given in the Fourth Gospel, and, indeed, this place seems to be important. In this vicinity, from among the circle of John the Baptist, Jesus won the first of his own disciples (In 1:29-51). To this place he fled at the end of his ministry, after an attempt to arrest him had been made in Jerusalem at the Feast of Dedication (10:31-40). Here in Bethany beyond the Jordan a great crowd of followers from the circle of John the Baptist came to him and believed in him (10:41-2). From these statements Karl Kundsin, ${ }^{8}$ and following him, Rudolf Bultmann,9 concluded that the historical core of the statement indicated that one had to accept the existence of a Christian congregation in this place. Subsequently the activity of John the Baptist and of Jesus himself was transferred there. But before we can evaluate this suggestion we ought to know where Bethany was actually situated.

\section{THE PROBLEM OF THE TEXT}

In the first half of the third century Origen could find no place on the east bank of the Jordan bearing this name. In his commentary on John's Gospel, he therefore proposed the name BฤӨaßapâ, although in his time almost $(\sigma \chi \in \delta 6 \nu)$ all the manuscripts read Bitavia. ${ }^{10}$ Also in our present-day collection of manuscripts

la tradition néotestamentaaire', Proche-Orient chrétien 34 (1984) 209-32.

7 The historicity of the Pella tradition is discussed by R. Pritz, 'On Brandon's Rejection of the Pella Tradition, Immanuel 13 (1981) 39-43 (with bibliography).

8 Topologische Uberlieferungsstoffe im Johannes-Evangelium (FRLANT 22; Göttingen, Vandenhoeck \& Ruprecht 1925) $20 \mathrm{f}$.

${ }^{9}$ The Gospel of John: A commentary (ET; Oxford, Blackwell 1971) 93f. n. 3. 
$B \eta \theta a v i a$ represents the majority reading. It has not only the codices Vaticanus (B) and Sinaiticus ( $*$ ) on its side, but it may be traced back in $\mathrm{P}^{75}$ to the third century, and in $\mathrm{P}^{66}$ even to the second quarter of the second century. ${ }^{11}$ The minority reading. $B \eta \theta a \beta a \rho a$, of which Origen is the first certain witness, exists in an abundance of orthographic variants. ${ }^{12}$ That is certainly an indication that in many instances there has been a conscious later alteration of the name of the place. The age and geographical distribution of the manuscripts, as well as the consideration that no really convincing reason exists for a later substitution of the

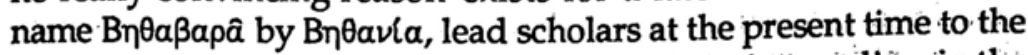
almost unanimous conclusion that the majority reading is the correct one. ${ }^{13}$ This is also supported by an argument from the general composition of the Gospel. When we compare John 1:28 with 10:40 and 11:1 we notice 'that the reading "Bethany" is intended by the Evangelist: Jesus comes from the place "Bethany beyond the Jordan" to the "Bethany" which was "near Jerusalem" (11:18). ${ }^{14}$ More pointedly, one can say: in John's Gospel Jesus' way leads from Bethany to Bethany.

The original reading of the text of John 1:28 is therefore well established. But it is important to remember that Origen according to the widely accepted results of recent investigation did not propose the name 'Bethabara' simply as an etymological conjecture when he interpreted the name as 'House of

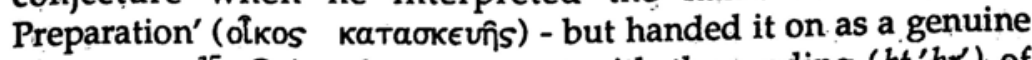
place-name. ${ }^{15}$ Origen's agreement with the reading $\left(b t^{\prime} b r^{\prime}\right)$ of the Old Syriac (syr $r^{s, c}$ ), whose place-names appear to rest on good information, ${ }^{16}$ speaks for the acceptance of a local tradition. But

10 Comm. in Ioann. VI. 204 (C. Blanc [ed.], Origene: Commentaire sur Saint Jean II [SC 157; Paris, du Cerf 1970] 284).

$11 \mathrm{Cf}$. H. Hunger, 'Zur Datierung des Bodmer II', Anzeiger der osterreichischen Akademie der Wissenschaften 4 (1960) 12-23.

12 There is a clearly presented listing in W. Wiefel, Bethabara jenseits des Jordan Joh. 1,28)', ZDPV 83 (1967) 72-81 (72f.).

13 Cf. B. M. Metzger, A Textual Commentary on the Greek New Testament (London-New York, UBS ${ }^{2} 1975$ ) 1996.

${ }^{14}$ B. Schwank, Das Johannesevangelium I (Düsseldorf, Patmos-Verlag 1966) 60.

15 Cf. e.g. C. K. Barrett, The Gospel According to St John (London, SPCK ${ }^{21978)}$ 175.

16 Cf. K. Beyer, Die aramäischen Texte tom Toten Meer (Göttingen, Vandenhoeck \& Ruprecht 1984) 50f. n. 1. See already M. J. Lagrange, 'L'origine de la version Syro-Palestinienne des évangiles', KB 34 (1925) 481-504 (489f.). 
when we attempt to discover the place referred to in John 1:28 on the basis of the statements of Origen, we find that more problems emerge rather than a solution. So it is not surprising that since the time of this great patristic biblical scholar there has been no lack of attempts to solve the geographical riddle of John 1:28.

\section{NEW AND OLD ATTEMPTS AT A SOLUTION}

\section{Obsolete Suggestions}

Eduard Schwartz declared that Bethany beyond the Jordan' was a subsequent interpolation of a redactor who was not conversant with the locality; ${ }^{17}$ Emanuel Hirsch regarded it as a corruption of the text. ${ }^{18}$ Both these suggestions were made before the discovery of $\mathrm{P}^{66}$ and $\mathrm{P}^{75}$, and since then, rightly, have no longer been advocated. Norbert Krieger held that 'Bethany beyond the Jordan' was a place of theological fiction. ${ }^{19}$ But since places mentioned by John which are able to be verified have generally proved to be trustworthy, as demonstrated in particular most recently by Benedikt Schwank, ${ }^{20}$ one should also here not readily begin by assuming that everything is unhistorical fiction.

\section{Was Bethany near Jerusalem?}

Pierson Parker identified the Bethany of John 1:28 with the Bethany named in John 11:1, 18 and 12:1, in that he interpreted $1: 28$ as follows: These things took place in Bethany, which is across from the point of the Jordan where John had been baptizing.'21 Like other audacious proposals, this suggestion is not as new as its author imagined. Long before him the rationalist Heinrich Eberhard Gottlob Paulus had attempted to interpret the designation in this way, 22 and as a result he fell under the reproach of Schleiermacher's pupil Friedrich Lücke: 'This

17 'Aporien im vierten Evangelium IV', NGWG.PH 1908 (Berlin 1908) 497-560 (521).

18 Studien zum vierten Evangelium. Text - Literarkritik - Entstehungsgeschichte (Beitråge zur historischen Theologie 11; Tübingen, J. C. B. Mohr 1936) 4.

19 'Fiktive Orte der Johannes-Taufe', ZNW 45 (1954) 121-3.

20 'Ortskenntnisse im Vierten Evangelium?', EA 57 (1981) 427-42.

21 ، "Bethany Beyond Jordan" ', JBE 74 (1955) 257-61 (258).

22 Das Leben Jesu, als Grundlage einer reinen Geschichte des Urchristentums I (Heidelberg, C. F. Winter 1828) 31. 
distortion of the text is ... intolerable.'23 In John 3:26 and 10:40

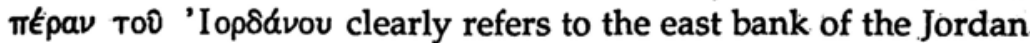
and there is no evident reason to accept any other interpretation here. ${ }^{24}$ It would also be especially remarkable if the Evangelist wanted to clarify the position of Bethany in his first mention of it with the help of a locality which had never been clearly defined. But rather he took every care to distinguish the two places: Jesus sets out from Bethany beyond the Jordan (Jn 1:28; cf. 10:40) towards the Bethany whose distance from Jerusalem is given with extraordinary accuracy as fifteen stadia (Jn 11:18).

Parker's hypothesis is also rejected by Robert T. Fortna. He writes: We can leave aside a number of questions the verse raises: whether John wrote Bethany or some other name. The archaeological identification of the place, even whether it is actual or fictitious. What concerns us here is only John's intent in introducing the notice. It has been ingeniously argued that he means not an otherwise unknown Bethany east of the Jordan, but the well known place of that name near Jerusalem. It seems to me more likely, however, that the usual interpretation of "across the Jordan" (peran tou Iordanou) is correct. But in any case, what emerges is that John puts the place of Jesus' first appearance in the south of Palestine'.25 Sometimes even ingenious source critics such as Professor Fortna have to handle such trivial real questions as topography. And sometimes the results are remarkable. Bethany may have been non-existent and its name even not Bethany, but in any case it was in the south. One is reminded of the Latin proverb: 'Homerum vixisse nescimus, caecum fuisse certum'.

\section{Was Bethany opposite Jericho?}

The site which in early Byzantine times ${ }^{26}$ was thought to be the

23 Commentar aber das Evangelium des Johannes I (Bonn, E. Weber $\left.{ }^{3} 1840\right) 394$.

24 Cf. J. R. Michaels, John (New York, Harper \& Row 1984), 17.

25 Theological Use of the Locale in the Fourth Gospel', in M. H. Shephard and E. C. Hobbs, Gospel Studies in Honor of Sherman E. Johnson (AThR Suppl. 3; London, SCM 1974) 58-95 (67). His note 33 is worth quoting: Parker's reading strains both grammar and geography; tou Iordanou is a real object of peran, and the hopou clause is used not relatively but appositively, as in 4:46; 12:1. If John had intended what Parker suggests he would have written peran tou Iordanou hopou - cf. 6:23; 10:40. Furthermore, it is hard to imagine anyone identifying a place near Jerusalem by reference to a point in the Jordan valley'.

26 The evidence for the tradition is collected in D. Baldi, Enchiridion Locorum 
place where Jesus was baptized can still be pin-pointed today. ${ }^{27}$ Close by the Latin site of the baptism (in the proximity of the Greek Monastery of St John) lay the ruins of that Church of St John ${ }^{28}$ which Theodosius visited about AD 530.29 These ruins, which have now disappeared, probably for ever, lay about fifty metres from the east bank of the river. From here the Wadi elCharrar, which at least from the time of the Pilgrim from Piacenza ${ }^{30}$ (about AD 570) was identified with the Brook Cherith of Elijah (1 Ki 17:5) runs inland. ${ }^{31}$ After a further two kilometres one reaches in the vicinity of a basin abounding in springs a hill with the name of Dschebel Mar Eljas. This hill is doubtless the one pointed out to the Pilgrim from Bordeaux ${ }^{32}$ in $\mathrm{AD} 333$ as the place where Elijah was taken up into heaven (2 Ki 2:5-14). ${ }^{33}$ Since the Pilgrim certainly followed a pre-Christian Jewish local tradition, ${ }^{34}$ the choice of this locality for baptizing could have been that of John himself, in order to point to himself as the Elijah of the end-times. ${ }^{35}$

About one and a half kilometres further up the wadi one finds a particularly gushing spring of water. Wolfgang Wiefel ${ }^{36}$ identifies it as the spring by which, according to the anonymous pilgrim from Piacenza, ${ }^{37}$. John baptized, as well as with the AINQN ENOA NYN O $\Sigma A I \Sigma A \Phi A \Sigma$ of the Madaba mosaic map (c. AD 560). Since the Jordan at floodtime could have been too dangerous for baptizing, ${ }^{38}$ it is quite credible that just as John

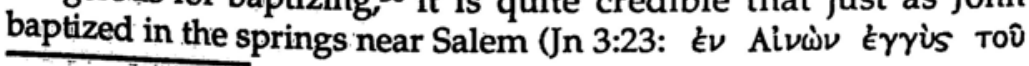

\footnotetext{
Sanctorum (Jerusalem, Franciscan Printing Press ${ }^{3} 1982$ ) $170 \mathrm{ff}$.

2 Cf. C. Kopp, Holy Places 113-29.

${ }^{28}$ Cf. W. Wiefel, ZDPV 83 (1967) $76 f$.
}

29 De situ terrae sanctae 20 (P. Geyer, Itinera Hierosolymitana [CSEL 39; Vienna, Tempsky 1898] 145).

30 Itinerarium 9 (CSEL 39, 165).

31 Today the Brook Cherith is usually identified with the Wadi el-Jabis opposite the Salem of John 3:23. Cf. P. Maraval, ÉgErie 192f. This proximity could have been an additional motive for John's choice of the place.

32 Itinerarium Burdigalense 19 (CSEL 39, 24).

${ }^{33} \mathrm{Cf}$. W. Wiefel, ZDPV 83 (1967) $75 f$.

${ }^{34}$ Cf. C. Kopp, Holy Places 115.

35 Cf. R. Schnackenburg, The Gospel According to St John I (ET; London, Burns \& Oates 1968) 296.

36 ZDPV 83 (1967) 76.

37 Itinerarium 9 (CSEL 39, 165).

38 Cf. M. J. Lagrange, Evangíle selon Saint Jean (Paris, Gabalda 61936) 39. 


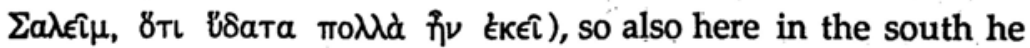
had a place for baptizing in one of the springs flowing into the Jordan, and whose waters were regarded as water of the Jordan river itself. ${ }^{39}$ Perhaps it was in connection with the regular celebration of the Feast of the Epiphany as the day on which Christ was baptized that the celebration of his baptism was transferred to the west bank of the river from the second half of the sixth century. 40

In the face of the high antiquity of the tradition for the Wadi el-Charrar it is understandable that today the Bethany of John 1:28 is usually located there, ${ }^{41}$ that is, if one does not hold the search to be totally futile. ${ }^{42}$ But are there any clues in the local lists of names? Gustav Dalman ${ }^{43}$ began his investigation from the Alvív of the Madaba map on the east bank of the Jordan opposite Jericho. He conjectured that there was here an older remembrance

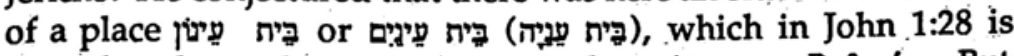

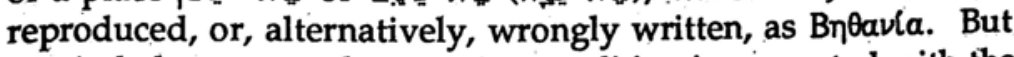
precisely because such an ancient tradition is connected with the Wadi el-Charrar it remains unintelligible why Origen should not have found the place-name Bethany so near to Jerusalem when there was supposed to be a trustworthy knowledge of it still in the sixth century. At the time of the Madaba map the place indeed

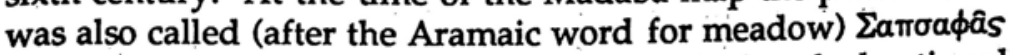
and with the name Alvóv was simply described as the baptismal spring mentioned by the Anonymous Placentinus.

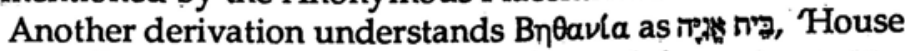

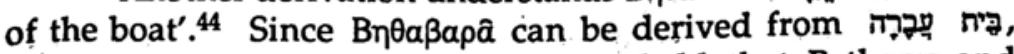
'House of the crossing', many have held that Bethany and Bethabara are two different names for one and the same ford of

39 Cf. H. Gese, Essays on Biblical Theology (ET; Minneapolis, Augsburg 1981) 219 n.29.

40 Cf. W. Wiefel, ZDPV 83 (1967) 77f.

41 E.g. by Schnackenburg, St John I, 296; B. E. Schein, Following the Way. The Setting of John's Gospel (Minneapolis, Augsburg 1980) 189; O. Keel and M. Küchler, Orte und Landschaften der Bibel 2: Der Süden (Zurich - Göttingen, Benziger - Vandenhoeck \& Ruprecht 1982) 527-32.

42 E.g. R. E. Brown, The Gospel according to John I (London, G. Chapman 1971) 44f.; L. L. Morris, The Gospel According to John (London, Marshall, Morgan \& Scott 1971) 142.

43 Orte und Wege Jesu (BFChTh II/1; Gütersloh, Bertelsmann 3924) $98 \mathrm{f}$.

44 Cf. A. Barrois, 'Bethanie', DBS I (Paris, Letouzey et Ané 1928) 968-70 (970). 
the Jordan. ${ }^{45}$ The first and only ancient identification of Bethabara which is beyond doubt is provided by the Madaba mosaic map, which places it in the region of the traditional site where John baptized Jesus, but on the west bank of the river. Hence one can question whether this identification goes back to earlier times. The statements of Origen unfortunately are inaldequate to make any firm identification. But perhaps the remarkable plural form тd $B \eta \theta a \beta a \rho a ̂$ which is found in Origen (Comm. in Ioann. VI. 205) indicates a number of fords across the Jordan near Jericho. The statements of Eusebius in his Onomastikon (58:19-20) show that this church historian thought of a definite place, ${ }^{46}$ yet here too specific statements as to its precise whereabouts are lacking. But since we have no indication that the traditions concerning the places changed between the times of Eusebius and the Madaba map, the best supposition is that the designation Bethabara actually in very early times was associated with the region of the traditional baptismal site. In order to locate the Bethany named in John 1:28 here, one must identify this site of John's ministry with the place where Jesus was baptized. But this assumption which is often tacitly presupposed is by no means cogent, as even advocates of this identification concede. ${ }^{47}$ The baptism of Jesus is mentioned in the Fourth Gospel only in an indirect way (Jn 1:32-34), and the name of the place is not given. So one cannot exclude the possibility that the identification of Bethabara opposite Jericho with the Bethany of John 1:28 represents only an old exegetical hypothesis which is not based on any genuine local tradition.

While the Wadi el-Charrar has at least an old local tradition in its favour, another attempt to identify Bethany beyond the Jordan with a site quite nearby rests solely on a modern supposition. Not far from the Allenby Bridge, at the mouth of the Wadi Nimrin, and on its north side, lies the hill called Tel elMedesh, also named Khirbet et-Tawil. On this site, about eight kilometres north of the Wadi el-Charrar, L. Federlin ${ }^{48}$ located the hill of Elijah and correspondingly the baptismal site at the most important ford of the Jordan named el-Ghoranije. ${ }^{49}$ A number of

45 C. C. Mommert, Aenon und Bethania. (Leipzig, E. Haberland 1903) 40, 56.

${ }^{46}$ Cf. T. Zahn, NKZ 18 (1907) 273.

47 Cf. Schnackenburg, St John I, 296.

48 Bethanie au dela du Jourdain (Paris n.d. [1908]). 
Catholic scholars initially followed him in this, ${ }^{50}$ but because no tradition is associated with the site this identification is scarcely advocated any more today. ${ }^{51}$

\section{Was Bethany at Bet Nimrah?}

George Grove ${ }^{52}$ suggested this location where the Wadi Shu'eb flows into the Jordan valley, and this hypothesis found a good reception among many English scholars. ${ }^{53}$ He regarded the name Baloavaßpa in Joshua 13:27 (LXX'B) as the starting-point of the corruptions $B \eta \theta a v i a$ and $B \eta \theta a \beta a p a$. But for this solution Grove had to postulate an original form of the name which is not found in a single New Testament manuscript. This procedure becomes even less admissible today in view of the increase of the number of manuscripts (see Section II) which we now possess. Moreover, Josephus knew of a place which still existed in his day under the

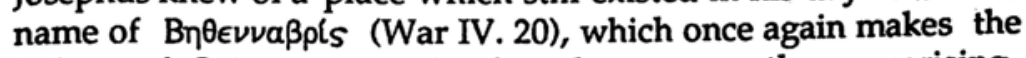
failure of Origen's search after the name rather surprising.

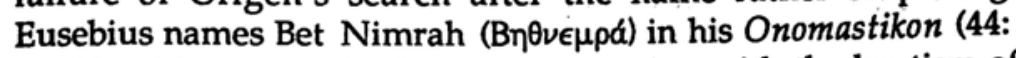
16-18), without mentioning any connection with the baptism of Jesus.

\section{Was Bethany at Betonium?}

The great Old Testament scholar Franz Delitzsch, who also wrote on the cultural background of the New Testament, , $^{54}$ suggested Batneh west-southwest of Es-Salt. ${ }^{55}$ Without reference to Delitzsch, Theodor Zahn ${ }^{56}$ in a study of the history of the

49 Concerning this ford sce H. Rix, Notes taken on a tour in Palestine in the spring of 1901', PEFQS 1903, 159-62 (161f.).

50 E.g. A. Barrois, 'Béthanic', 968-70; Lagrange, Saint Jean 39.

51 An exception is M. Avi-Yonah, Gazetteer of Roman Palestine (Qedem 5; Jerusalem, Hebrew University 1976) 37.

52 Cf. T. K. Cheyne, 'Bethany', Encyclopaedia Biblice I (London, A and C Black 1899) col. 548.

53 .E.g. J. H. Bernard, An Exegetical and Critical Commentary on the Gospel according to St John I ([ed. A. H. McNeile] Edinburgh, T \& T Clark 1928) 42; F. F. Bruce, The Gospel of John (Grand Rapids, Eerdmans 1983) 51, 66 n.45.

54 E.g. Ein Tag in Kapernaum (Leipzig, J. Naumann ${ }^{3} 1886$ ).

55 Torae Hebraicae et Talmudicae. Ergänzung zu Lightfoọt und Schöttgen', ZLThK 37 (1876) 593-606 (602).

56 'Zur Heimatkunde des Evangelisten Johannes', NKZ 18 (1907) 265-94 and earlier in his. Einleitung in das Neue Testament II (Leipzig, A. Deichert 1899) 561. 
transmission of the text which has not yet been superseded, decided on this site, and, apparently quite independently of both these scholars, also Konrad Furrer. ${ }^{57}$ Khirbet Batneh is to be identified with the Betonim ( Joshua 13:26.58 In the time of Eusebius the site still bore its old

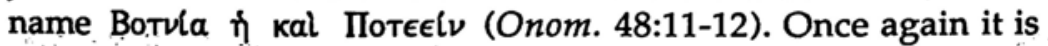
significant that Origen found no tradition there and that there is no mention in Eusebius that the site had any significance in the life of Jesus. Moreover, Paul Billerbeck ${ }^{59}$ rightly made the objection against Delitzsch that Betonim was unsuitable for a baptismal site, since it was neither situated on the Jordan nor possessed of its own spring. Zahn sought to weaken the force of this objection with the supposition that John had always held his sabbath rest here. ${ }^{60}$ But that seems to read back into the Palestinian culture of the first century too much of the modern need for relaxation.

\section{Was Bethany at the Abarah Ford?}

From the general context of John 1-2 (which is still to be discussed - see Section IV.2 below), Claude R. Conder concluded that the region referred to in John $1: 28$, for which he originally preferred the variant Bethabara, must have been further north in the Jordan valley than the traditional site of Jesus' baptism. ${ }^{61}$ While making investigations for the 'Survey of Western Palestine' he was told of a ford five kilometres northeast of Beth Shean called Makhadhet 'Abarah and this he identified as Bethabara. Not only did English scholars follow this suggestion, 62 but also a sceptically inclined exegete such as Karl Ludwig Schmidt ${ }^{63}$ and a Palestinian expert of the stature of Peter Thomsen. ${ }^{64}$ In 1928 Karl Erbes could even 57 'Das Geographische im Evangelium nach Johannes', ZNW 3 (1902) 257-65
(257f.).

${ }_{59}^{58}$ Cf. R. de Vaux, 'Exploration de la région de Salt', KB 47 (1938) 398-425 (404).

59 Kommentar zum Neuen Testament aus Talmud und Midrasch II: Das Evangelium nach Markus, Lukas und Johannes und die Apostelgeschichte (Munich, C. H. Beck 1924) 363.

${ }^{60}$ NKZ 18 (1907) 292.

61 The Site of Bethabara', PEPQS (1875) $72-4$.

62 E.g. A. Henderson, Palestine: Its Historical Geography (Edinburgh, T \& T Clark 1884) 153f; W. Sanday, Sacred Sites of the Gospels (Oxford, Clarendon 1903) 23,35 .

${ }^{63}$ Der Rahmen der Geschichte Jesu (Berlin, Trowitzsch \& Sohn 1919) 206. 
speak of a 'unanimous acceptance, ${ }^{65}$ whereas this supposition is only rarely advocated today. ${ }^{66}$ One must say, however, that, some three decades after Conder, Marie-Joseph Lagrange ${ }^{67}$ and Herbert Rix were not able to verify the name among the inhabitants of the area. Certainly Rix emphasized: Negative evidence of this kind does not, of course, carry very much weight, ${ }^{\prime 68}$ but the identification of Bethabara through the tradition in the south near Jericho (see Section III.3) adds to the arguments against this thesis. Incidentally, John Lightfoot had already advocated a similar view to that of Conder, in that he identified Bethabara with the Bethbarah of Judges 7:24 and sought it as a ford in the vicinity of Beth Shean. ${ }^{69}$ Bethbarah is difficult to locate, but today one usually accepts the location as being a region much further to the south (somewhere opposite the mouth of the Jabbok). ${ }^{70}$ Conder seems to have been unaware of Lightfoot's hypothesis, although at that time a new edition of Lightfoot's Horae Hebraicae et Talmudicae had just appeared in English translation. ${ }^{71}$

\section{Was Bethany near Bethsaida?}

A suggestion that Bethany was even further to the north, namely between the Lakes Huleh and Gennesaret in the region of the 'Bridge of the Daughters of Jacob,' was advocated by Samuel Basnage in 1706 in one of the first more modern works on the historical background of the New Testament, although he gave no evidence for this view. ${ }^{72}$ On account of the distances separating:

64 'Palästina nach dem Onomasticon des Eusebius' [map], ZDPV 26 (1903) after 144.

65 'Die Tauforte des Johannes nebst dem Salem des Melchisedek', TAWPVR 24 (1928) 71-106 (82).

66 The plausibility of the identification is discussed by S. Voigt, Topo-Geografia e Teologia del Battista nel IV Vangelo', LA 27 (1977) 69-101 (75 n.17).

67 'Origène, la Critique Textuelle et la Tradition Topographique', RB 4 (1895) 501-24 (510).

68 PEPQS (1903) 161.

69 Horae Hebraicae et Talmudicae in Quattuor Evangelistas (ed. J. B. Carpzov; Leipzig 1670) 911-16.

70 Cf. Y. Aharoni - M. Avi-Yonah, The Macmillan Bible Atlas (London, Macmillan 1977) 54 [map 76].

71 Horae Hebraicae et Talmudicae: Hebrew and Talmudical Exercitations I-IV (Oxford, University Press 1859) I, 327-33. 
the places mentioned in John 1-2, and a linking of John 1:28; 10:4041 with Matthew 19:1 (see Section V.3) the Jewish-Christian scholar Christian Eduard Caspari was also convinced that Bethany was to be located in the north, ${ }^{73}$ and suggested as its location the hill of ruins called et-Tel on the east bank of the Jordan, about two kilometres from where the river flows into the Sea of Galilee. In doing this, however, he wrongly disputed the identification of et-Tel with Bethsaida-Julias. ${ }^{74}$ Besides that he fell into error as the result of a printing mistake in the travel account of Ulrich J. Seetzen, ${ }^{75}$ where in the Latin transcription the Beduin village on the hill, instead of its true Arabic form Tellawije bears the incorrect name Tellanije, from which Caspari derived the Hebrew name Betanije.

On quite similar grounds to those of Caspari, although without mentioning any predecessors, Stanislas Dockx recently opted for a location near Bethsaida. ${ }^{76}$ In an additional piece of wild speculation in history-of-religions he concluded from the account of the baptism of Jesus where the Holy Spirit appeared in the form of a dove (Mt 3:16; Mk 1:10; Lk 3:22; Jn 1:32) that a preIsraelite river-god cult had existed in the Wadi ed-Dalije, about two kilometres southeast of et-Tel. Thus, as we will see (Section IV), the general reasons of Caspari and Dockx for locating Bethany in the north are worth consideration, but not their suggestions as to the actual sites.

\section{Was Bethany the Batanaea?}

Claude R. Conder" later changed his opinion about the textual

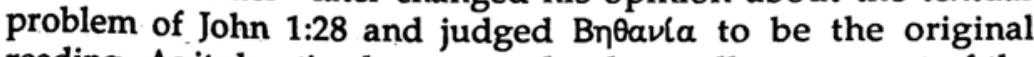
reading. As its location he proposed - above all on account of the reading in the Targums (see Section V.1) - the region of Batanaea,

\footnotetext{
72 Annales Politico-Ecclesiastici Annorum DCXLV a Caesare Augusto ad Phocam usque (Rotterdam, R. Leers 1706) 244.

73 Chronologisch-geographische Einleitung in das Leben Jesu Christi (Hamburg, Rauhes Haus 1869) 79-81.

74 Cf. however B. Pixner, 'Searching for the New Testament Site of Bethsaida', BA 48 (1985) 207-16.

75 Reisen durch Syrien, Paldstina . . . (Berlin 1854) I 354. Cf. C. Kopp, Holy Places 238f. Also inclining to this vicinity is D. Flusser, Jesus (ET; New York, Herder \& Herder 1969) 30 f.

76 'Béthanie au-delà du Jourdain' in Chronologies néotestamentaires et Vie de l'Église primitive, (Louvain, Peeters ${ }^{2} 1984$ ) 12-20.

7 Bethany Beyond Jordan', PEFQS (1877) 184-6.
} 
the Bashan of the Old Testament. Here also Conder could have found an earlier reference in John Lightfoot. ${ }^{78}$ On the basis of a hint from the Dominican exegete Marie-Émile Boismard, William H. Brownlee took up Conder's thesis and sought to establish it in more detail. ${ }^{79}$ Apparently in complete independence of everyone else the German lawyer Karl August Eckhardt, who was interested in theology, proposed the same solution..$^{80}$ Bargil Pixner I have already mentioned. When such a variety of scholars at such different times independently come to the same proposal,

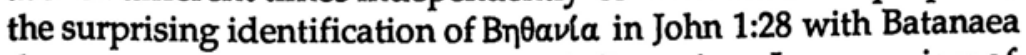
does not seem, at least, to be beyond discussion. In our review of the various proposals for a solution we have found that along with the view that identifies Bethany with the Wadi el-Charrar opposite Jericho, only this other attempt at a solution, namely that Bethany is to be identified with Batanaea, is worthy of consideration. It would be one step towards a possible solution if one could decide whether Bethany was in the north or in the south.

\section{THE NECESSITY OF A LOCATION IN THE NORTH}

\section{The Statements regarding Time in John 11}

In Bethany beyond the Jordan (Jn 10:40; cf. 1:28) Jesus received the news that Lazarus was seriously ill in Bethany near Jerusalem (11:1-3; cf. 11:18). After the messenger arrived Jesus remained two days in the same place (11:6). When he arrived at Bethany in Judaea (cf. 11:7) he found that Lazarus had already been lying in the tomb for four days (11:17; cf. 11:39). In order to be able to evaluate these statements regarding time and the questions of distance which are connected with them, we must keep in mind that the Wadi el-Charrar lies exactly a day's journey away from Bethany near Jerusalem. In regard to this matter of time and distance, questions as to the historicity of John 11 in details may be omitted. It is enough to ask what conception guided the evangelist in regard to the geographical situation.

\section{Horae Hebraicae 912.}

79 Whence the Gospel According to John?' in: J. H. Charlesworth (ed.), John and Qumran (London, Geoffrey Chapman 1972) 166-94 (167-73).

80 'Zur Taufe im Jordan' in id., Der Tod des Johannes als Schlulssel zum Verständnis der Johanneischen Schriften (Berlin, de Gruyter 1961) 168-71. 
In order to be able to identify the place where Jesus was staying in John 10:40 with the traditional place of his baptism opposite Jericho, one must presuppose that Lazarus died and was buried on the same day as the messengers arrived (Day 1). After remaining two days there Jesus then arrived at Bethany near Jerusalem on the fourth day. ${ }^{81}$ But against such a reckoning we have the following objections: (1) even if the burial of Lazarus took place on Day 2 - which is likely to be the earliest moment - it would mean that Jesus had two days to make the journey, which is one day too many. (2) The difference in the formulations between John 11:4 and 11:11 should be noticed. On the arrival of the messengers Jesus declares: "This illness ( $a \sigma \theta \epsilon \nu \in L a$ ) is not unto death, but for the glory of God' (11:4). On the other hand he substantiates his departure for Judaea with the words: 'Lazarus our friend has fallen asleep (кєко' $\mu \eta$ Tal [11:11])' and means by this statement that he has died (11:13). The most natural understanding of this passage is that Lazarus was still alive when the messengers arrived, whereas Jesus makes ready to depart precisely at the time when, in a miraculous way, he experiences inwardly the death of his friend. (3) Only in this way can the motive for Jesus' delay of two days be satisfactorily explained from the point of view of composition and theology. 'In allowing Lazarus to die,' writes William H. Cadman, 'He was providing

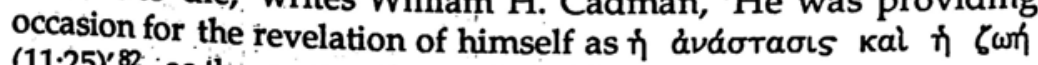
$(11: 25)^{\prime} 2_{-}$- as the resurrection and the life.

The four days in which Lazarus lay in the grave ${ }^{83}$ must, therefore, be reckoned from the departure of Jesus from Bethany beyond the Jordan. This means that the two Bethanies were separated from each other by a distance of three or four days' journey, and this fact completely excludes the traditional site of Christ's baptism as the starting-point. We know that the average day's march in Palestine in New Testament times was about 40 kilometres. Mishnah (Ta'an 1,3) and Talmud $(b$ Pes 93b) give about 45 kilometres for a full day's march, ${ }^{84}$ which is confirmed 81 So, finally, E. Delebecque, "Lazare est mort" (note sur Jean 11,14-15)', Bibl 67
(1986) $89-97$ (91).

82 The Raising of Lazarus John 10,40 - 11,53)', TU 73 (1959) 423-34 (426).

83 In any case, according to the rabbinic opinion, that the soul hovered near the body for three days (P. Billerbeck, Kommentar zum Neuen Testament aus Talmud und Midrasch II, 544), there was by now no hope of resucitation for Lazarus.

$84 \mathrm{Cf}$. G. Dalman, Orte und Wege Jesu 243f. Of course, this is true of a band of 
by Josephus (Vita 269-70). For him even to walk a distance of 30 stadia (little less than 6 kilometres) in one hour seemed possible. ${ }^{85}$ All this would place both Bethanies at a distance of about 150 kilometres apart. This fact runs counter not only to the Wadi elCharrar as the site of Bethany beyond the Jordan; every other site in the Peraea of Antipas is likewise excluded, since none of them is more than two days' journey distant from Jerusalem. Neither can the unknown Bethany lie roughly 150 kilometres eastwards from Jerusalem since this would lead us into the Arabian desert. Thus the trail indicates rather a north-easterly direction. Even Rudolf Schnackenburg, who preferred a location in the south, left open the possibility that a pre-Johannine source for 1:28 could have presupposed a location in Galilee. ${ }^{86}$

\section{The Time-Plan in John 1-2}

Like many modern exegetes after him, Origen (Comm. in Ioann. VI. 258-9) recognized six days in John 1: four days on the basis of the thrice-repeated phrase 'the next day' (Tn Emauplov) (1:29, 35, 43), plus two days, in that the 'third day' in 2:1 is counted from the last-mentioned day in 1:43. Yet last century Ferdinand Christian Baur perceived correctly that in 1:39 a full day is presupposed during which the two unnamed disciples of John stayed with Jesus, so that 1:41 forms a new statement. ${ }^{87}$ In patristic times a few of the Old Latin translations $\left(\mathrm{b} \mathrm{e}^{1}\right.$ ) understood the $\pi \rho \omega \hat{T}$ To in $1: 41$ in the sense of a $\pi p \omega t$, and therewith as the beginning of a new day. We obtain in this way a plan for a whole week, and in support of this procedure we find the parallel of the Passion week at the end of the gospel (Jn 12:1; 20:1) ${ }^{88}$ The following timetable ${ }^{89}$ summarizes the events in John 1:

men like the disciples. A caravan, e.g. pilgrims including women and children (cf. Lk 2:44), could only make a shorter distance. Cf. J. Jeremias, Jerusalem in the Time
of Jesus. An Investigation into Economic and Social Conditions during the New Testament Period (ET; London, SCM 1969) 60.

85 Cf. F. M. Abel, 'La distance de Jérusalem à Emmaüs', RB 34 (1925) 347-67 (366).

${ }^{86}$ T he Gospel according to St John II (London, Burns \& Oates 1980) 515 n.39.

87 Kritische Untersuchungen über die kanonischen Evangelien (Tübingen, L. F. Fues 1847) 114f. n.1.

88 C. J. N. Sanders, A Commentary on the Gospel according to St John, ed. B. A. Mastin, (London, A \& C Black 1968) 107f., $282 \mathrm{f}$.

$89 \mathrm{Cf}$. already C. J. Cadoux, 'The Johannine account of the early ministry of Jesus', JIS 20 (1919) 311-20 (311f.). 


\section{DAY JOHN EVENTS}

1. 1:19-28 The Baptist in Bethany beyond the Jordan.

2. 1:29-34 Jesus with the Baptist in Bethany.

3. $\quad 1: 35-9$ Calling of the first disciples at Bethany about the 10th hour (4 pm); afterwards they remain at the place where Jesus is staying.

4. 1:40-2 Calling of Peter from Bethsaida.

5. 1:43-51 Departure for Galilee; calling of Philip from Bethsaida and of Nathaniel from Cana in Galilee (Jn 21:2).

6.

7. 2:1-11 On the third day (reckoned from the last one named) a marriage at Cana in Galilee.

Marie-Émile Boismard ${ }^{90}$ rightly draws our attention to the fact that the special emphasis given to (1) the 'third day' (Jn 2:1), which according to established early Christian language (Mt 16:21; $17: 23$; 20:19; Lk 24:7, 46; Acts 10:40; 1 Cor 15:4) refers to the day of Jesus' resurrection; and to (2) the 'hour of Jesus' (Jn 2:4), that is his death on the cross $(7: 30 ; 19: 26 ; 20: 13,15)$, indicates in John chapters one and two a chronology with theological significance. On the other hand John A. T. Robinson, ${ }^{11}$ in his pleasant striving to demonstrate the historical trustworthiness of the Fourth Gospel, denies this plan for the week. His main argument is that the 'third day' of 2:1 refers to the Jewish week (Tuesday) on which pious Jews today often hold their marriages. But, as Robinson himself concedes, there is no evidence for this from ancient times. The Mishnah (Ket 1:1) and Talmud (bKet $2 a)$ even expressly

90 Synopse des quatres evangiles III: Jean (Paris, du Cerf 1977) 105.

91 The Priority of John (London, SCM 1985) 161-8. 
recommend other days for marriage. One should be careful about adopting unnecessary alternatives and not too hastily exclude the possibility that behind theological significance in John's Gospel there can at the same time be a real geographical-chronological framework. At any rate, in the same context the fourth Evangelist shows himself familiar with the locality when he distinguishes 'Cana in Galilee' (Jn 2:1, 11) from another Cana, presumably the Cana in Lebanon mentioned in Joshua 19:28.92 This indicates that at the least he could write a theologically motivated literary composition within a plausible geographical and chronological framework. Even Alfred Loisy, who was no conservative exegete, would have agreed with this in respect to our particular text. ${ }^{93}$

On the morning of the fourth day, according to the above timetable, Jesus is still in the proximity of Bethany beyond the Jordan (Jn 1:40-2). On the fifth day (1:43) he finally departs for Galilee. For this journey he has at the most only two days, for on the seventh day he is at Cana in Galilee taking part in a marriage feast. Presumably the fourth Evangelist has reckoned on only one day for the journey for on the fifth day Jesus calls two disciples whose home is in Galilee (1:43-51) and seems already to have arrived at the region. ${ }^{94}$ If the marriage took place on a Sunday, as the parallel of the Passion week suggests, then the sixth day would have fallen on a Sabbath, which would explain why there is no account of Jesus' activity. ${ }^{95}$ From the Wadi el-Charrar it is impossible to reach Cana in one or two days' journey. For the shortest way from Lower Galilee through Samaria to Jerusalem Josephus reckons three days (Vita 269-70). A distance between Cana and Bethany of not more than a day's journey would lead us to suppose that Bethany beyond the Jordan lies nearer to Galilee than to Judaea.

\section{Persons and Places in John 1}

Among the disciples from the circle of John the Baptist whom Jesus wins during one day in Bethany beyond the Jordan there is

92 Cf. R. M. Mackowski, "Scholar's Qanah". A Re-examination of the Evidence in Favor of Khirbet-Qanah', BZ 23 (1979) 278-84 (278f.); W. J. Bittner, Jesu Zeichen im Johannesevangelium (WUNT II/26; Tübingen, J. C. B. Mohr 1987) 94f.

\$ Le quatrième Évangile (Paris, Picard 1903) 213.

94 Cf. J. N. Sanders, John $108 \mathrm{f}$.

95 Op. cit. 108. 
Andrew and an unknown disciple of John (Jn 1:35-9). On the next day Andrew finds his brother Simon and leads him to Jesus (1:402). On the day after this, when Jesus has departed for Galilee yet is still in the vicinity of Bethany, they meet Philip who was 'from Bethsaida, the city of Andrew and Peter' (1:44). Within three days, and more or less at the same place, Jesus calls three disciples, all of whom come from the city at the point where the Jordan enters the Lake of Gennesaret. Such a gathering of Galileans as John 1 supposes appears astonishing at the lower reaches of the Jordan, and improbable, when we take into consideration our discussion of the distances. Now the calling of the disciples in John 1 is plainly a variation of the Synoptic accounts of the calling on the northwest bank of the Sea of Galilee (Mt.4:18-22 // Mk 1:16-20; cf. Lk 5:1-11).96 When John, with the explainable exception of the delegation from Jerusalem (1:19), mentions here only Galilean names, he indicates thereby what he also knows, that these events took place in the north. Fitting well into this picture is John 1:42 where we have a clear allusion to Peter's confession. According to the Synoptics this took place at Caesarea Philippi (Mt 16:13-23 // Mk 8:27-33); according to John at least somewhere in the north (cf. Jn 6:67-9). When we collect together all the observations we have made, we will have to agree with Karl Elliger that 'according to the context of Jn 1f. . . . Bethany beyond the Jordan must be sought nearer to Galilee than
to Judaea.' 97

\section{BEYYOND THE JORDAN}

The location in the north would not be tenable if $\pi \epsilon \rho a \nu$ Tov Iopsávou in John 1:28 refers to the Peraea of Herod Antipas in the political sense. Yet although this meaning of the phrase is again and again tacitly presupposed, it is by no means certain. At this point we must once again examine the statements of the Gospels.

\section{The List of Regions in Matthew 4:25 and Mark 3:7-8}

Mark 3:7-8 designates the origin of the crowds that came to Jesus with, remarkably, seven geographical names: Galilee, Judaea,

96 Cf. C. H. Dodd, Historical Tradition in the Fourth Gospel (Cambridge, CUP 2 1965) 305.

97 Bethanien (BHH I; Göttingen, Vandenhoeck \& Ruprecht 1962) 230f. (231). 


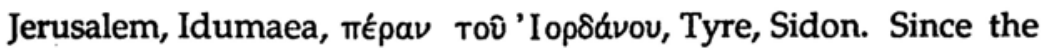
term 'beyond the Jordan' follows the name Idumaea, one could quite naturally understand it to refer to the Peraea of Antipas. In favour of this is the fact that in the parallel passage Luke 6:17,

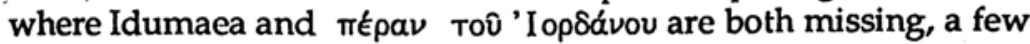
manuscripts $\left(\kappa^{*} \mathrm{~W} \mathrm{ff}^{2}\right)$ read kal Tîs IIepalas. But this reading is certainly not original, ${ }^{98}$ and since the enumeration with Tyre and

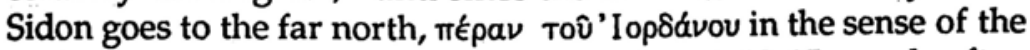

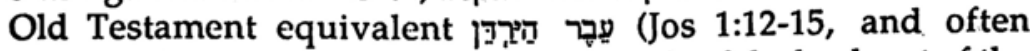
elsewhere), can just as well mean the whole of the land east of the Jordan (including the Decapolis, Gaulanitis and Basanitis).

The Matthean parallel to our list (Mt 4:25) enumerates, also remarkably, five regions from which the people came: Galilee, the

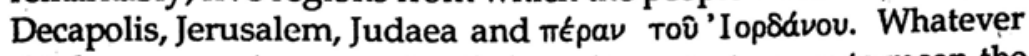
this last expression may signify here, it must at any rate mean the land east of the Jordan, for in Matthew's Gospel it certainly cannot mean Samaria (cf. 10:5), nor can it mean Idumaea. The related phrase $\epsilon l s$ to $\pi \epsilon p a \nu$ always refers to the east bank of Lake Gennesaret (Mt 8:18, 28; 14:22; 16:5). This fact completely disproves the view, advocated above all by $\mathrm{H}$. Dixon Slingerland,

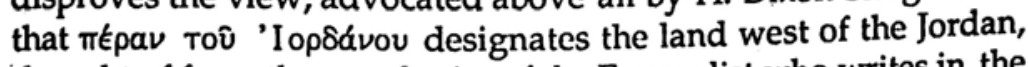
thought of from the standpoint of the Evangelist who writes in the Decapolis. ${ }^{99}$ If one sees in Matthew 4:25 a strict north-south division in the order of the names, then the most natural view would be that the southern land cast of the Jordan, namely Peraea, is meant. However, a second occurrence of the phrase in Matthew indicates the northern land east of the Jordan.

\section{The Reflective Citation, Matthew 4:13-16}

For the first Evangelist the prophecy of Isaiah 8:23-9:1 (Mt 4:13-14) is fulfilled when Jesus comes to dwell in Capernaum. In this regard Matthew is led by definite geographical conceptions: 'the land of Zebulun and the land of Naphthali, by the way of the sea,

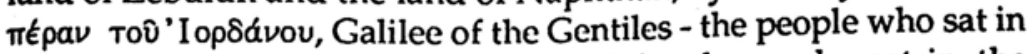
darkness have seen a great light, and for those who sat in the

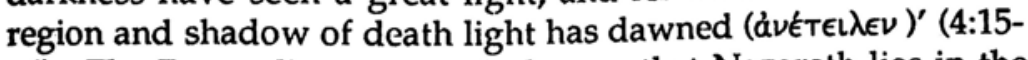
16). The Evangelist apparently knows that Nazareth lies in the

98 Cf. J. A. Fitzmyer, The Gospel According to Luke I-IX (New York, Doubleday 1981) 623.

99 The Transjordanian Origin of St Matthew's Gospel', JSNT 3 (1979) 18-28. 
tribal area of Zebulon, and Capernaum in the bordering region of Naphthali. ${ }^{100}$ More difficult to interpret are the three following geographical designations. With respect to their meaning in Isaiah itself there is no unanimity among Old Testament exegetes. ${ }^{101}$ Since Matthew just previously has spoken of

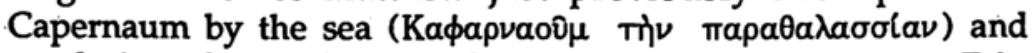
speaks just afterwards of the Sea of Galilee ( $\theta \dot{\alpha} \lambda \alpha \sigma \sigma \alpha$ Tîs $\Gamma a \lambda_{l}$ -

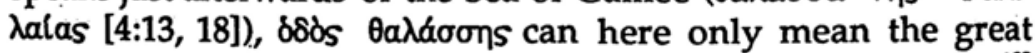
connecting road between Caesarea Maritima and Damascus, ${ }^{102}$ which at Capernaum touches the northwest bank of Lake Gennesaret. ${ }^{103}$ According to Matthew's understanding $\pi \epsilon \rho a \nu$ To 'Iop\&́vou must have been situated in the neighbourhood of the above-named regions and hence the designation must pertain to the northern land east of the Jordan. Naturally, it would be tempting in this context to allow, with Ernst Lohmeyer,' 104 'Galilee of the Gentiles' to extend into the northern land east of the Jordan, but this interesting hypothesis cannot be discussed here.

The messianic expectation which is becoming visible in the reflective citation of Matthew 4:13-16 also indicates that the northern land east of the Jordan is being referred to. Jerome knew of a Jewish-Christian interpretation of Isaiah 8:23-9:1 which takes up ancient Jewish traditions (see Section VI 2-3), according to which the Christ, in an antitypical way, is supposed to have begun his work of salvation precisely in the place where for Israel all the trouble began - in the extreme north. ${ }^{105}$ According to 2 Kings 15:29 the first regions to fall to the Assyrians in the year 733-2 BC were 'Gilead and Galilee, the whole land of Naphthali', along with a few individually named towns. Matthew has replaced the 'shining of light' (ר) 100 Cf. A. Schlatter, Der Evangelist Matthäus (Stuttgart, Calwer V. 1929) 114.

101 Cf. H. Wildberger, Jesaja I (BK X/1; Neukirchen-Vluyn, Neukirchener V. 1972) 372f. with O. Kaiser Isaiah 1-12 (ET; London, SCM 21983) $204 f$.

102 Cf. U. Luz, Das Evangelium nach Matthäus (Mt 1-7) (EKK I/1; NeukirchenVluyn, Neukirchener V. 1985) 172.

108 Cf. B. Pixner, 'Les routes de Jésus autour du Lac', MB 38 (1985) 14-16.

104 Galiläa und Jerusalem (FRLANT 34; Göttingen, Vandenhoeck \& Ruprecht 1936).

105 Comm. in Is. 9:1 (130), RL 24, 128. A. F. J. Klijn, 'Jerome's quotations from a Nazorean interpretation of Isaiah', RSR 60 (1972) 241-55 (251-2 n.46), in my opinion wrongly, doubts that Jerome received the tradition as an interpretation of Is 9:1. 
dawning of light' ( $\phi \omega \hat{s}$ à $\nu \epsilon \in \epsilon \iota \lambda \epsilon \nu$ [Mt 4:16]), and thus created a connection with the prophecy of Balaam in Numbers 24:17 ( the messianic star (Mt 2:2, 9; cf. Is 58:10) was connected especially with the land south of Damascus. ${ }^{107}$ For Josephus the territory of Naphthali reached right to Damascus (Ant. V. 86). How important the south part of Syria was to Matthew ${ }^{108}$ is shown in 4:24: 'And his [i.e. Jesus'] fame spread throughout all Syria ( $\epsilon$ is

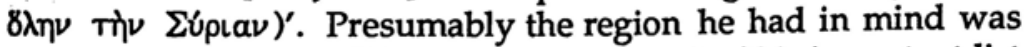
that south of Hermon. ${ }^{109}$ So when at the end of his important list of regions in 4:25 the Evangelist emphasizes that from $\pi \epsilon \rho a \nu$ Tov 'Iopódvov also crowds of people have come to Jesus, he could certainly have meant the northern land east of the Jordan, ${ }^{110}$ which for him was obviously a most important area.

\section{Matthew 19:1, Mark 10:1 and John 10:40-42}

According to John 10:40 'Bethany beyond the Jordan' became a place of refuge for Jesus, after the Jews had attempted to stone him during the Feast of Dedication in Jerusalem. ${ }^{111}$ If we take care to understand the circumstances of the historical situation, then it becomes clear that $\pi \epsilon \rho a \nu$ Tov 'Iopठdévov cannot mean the Peraea of Antipas. For there, at the end of his ministry, great danger threatened Jesus, as the old pre-Lucan tradition Luke 13:31-3, among other references, informs us. ${ }^{112}$ The 'beyond the Jordan' of John 10:40 must therefore be sought either in the Decapolis or in the tetrachy of Philip (Gaulanitis, Basanitis and Trachonitis), who, Josephus tells us (Ant. XVIII 106-7), was a tolerant ruler. Since John reports a successful preaching ministry of Jesus (Jn 10:41), it is more likely that this took place in the territory of Philip than in

106 Cf. R. H. Gundry, Matthew (Grand Rapids, Eerdmans 1982) 60f.

107 Cf. J. Daniélou, Primitive Christian Symbols (London, Burns \& Oates 1964) 102-23.

108 Cf. especially G. Lohfink, Wem gilt die Bergpredigt? Eine redaktionskritische Untersuchung von Mt 4,23-5,2 und 7,28f.', ThQ 163 (1983) 264-84 (273f.).

109 Cf. M. J. Lagrange, Évangile selon Saint Matthieu (Paris, Gabalda 51941) 72.

110 So also K. S. Krieger, 'Das Publikum der Bergpredigt (Mt 4, 23-25)', Kairos 28 (1986) 98-119 (104f.).

111 Cf. Schnackenburg, St John II 314.

112 Cf. J. Jeremias, Neutestamentliche Theologie I: Die Verkündigung Jesu (Gütersloh, Gerd Mohn ${ }^{2} 1973$ ) 266f., and also H. W. Hoehner, Herod Antipas. A Contemporary of Jesus Christ (Grand Rapids, Zondervan 1980) 214-23, 317-30. 
the Decapolis where the Jews formed only a minority of the people.

Exegetes from ancient and modern times have pointed out that a certain parallelism exists between John 10:40-2 and Matthew 19:1 // Mark 10:1:113 (1) shortly before Passion week (2) Jesus flees (3) to the other side of the Jordan, and (4) once more draws a great number of people to himself. It is true that in Matthew 19:1 //

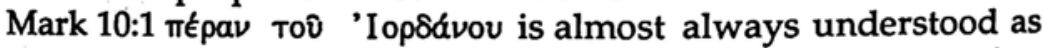
the Peraea of Antipas, but against this interpretation is the fact

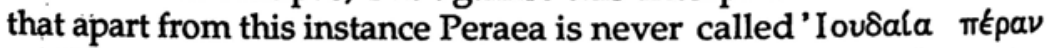

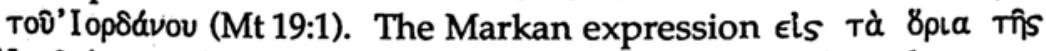

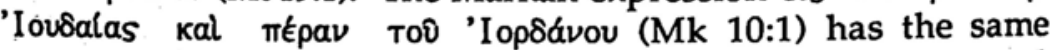
meaning. The conjunctive $k a l$, which textual critics rightly regard as the original reading, ${ }^{114}$ corresponds thoroughly to Markan style, ${ }^{115}$ and is to be understood as an explicative: ${ }^{116}$ '[Jesus] came to Judaea and, indeed, beyond the Jordan.'

In order to solve the topographical riddle 'Judaea beyond the Jordan', a hint from Karl von Raumer, who wrote a remarkable book on the geography of Palestine in the middle of the last century, is helpful. ${ }^{117}$ In the description of the boundaries of Naphthali in the Masoretic text of Joshua 19:34 we find the peculiar sentence: Naphthali touches on Zebulon at midday, on

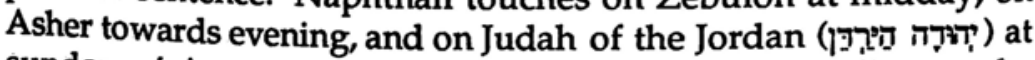
sundown.' As a rule the passage is corrected according to the Septuagint, where a correspondence to the problematic expression ידin is missing. ${ }^{118}$ But according to the evidence of other citations Matthew read also the Hebrew text. ${ }^{119}$ Three things may indicate that in Matthew 19:1 there is a deliberate reference back to Joshua 19:34: (1) as the parallel Matthew 4:15 (Section V.2) shows, $\pi \epsilon p a v$ Tov 'Iop\&dvou can concern the borders of Naphthali. (2) 'Iov\&ala

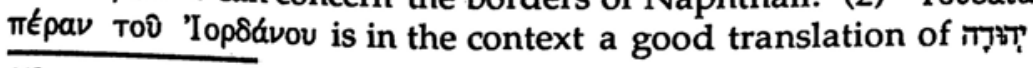

113

C. e.g. J. A. Bengel, Gnomon Novi Testamenti (ed. E. Bengel; Tübingen, L. F. Fues ${ }^{3} 1855$ ) 367 n.1; Brown, John I 414; G. Maier, Johannes-Evangelium 1 (BibelKommentar 6; Neuhausen - Stuttgart, Hänssler 1984) 474.

114 Cf. H. D. Slingerland, JSNT 3 (1979) 2 of.

${ }^{115} \mathrm{Cf}$.

116 Cf. F. G. Lang, ZDPV 94 (1978) 146 n.4; 154 f. n.57.

117 Palästina (Leipzig, F. A. Brockhaus ${ }^{4} 1860$ ) 233-41.

118 Cf. M. Noth, Das Buch Josua (HAT 7; Tübingen, J. C. B. Mohr $\left.{ }^{2} 1953\right)$ 116, 120.

119 Cf. e.g. R. H. Gundry, The Use of the Old Testament in St. Matthew's Gospel (NovTS 18; Leiden, E. J. Brill 1967). 
(3) In Joshua 19:34 (LXX) the Hebrew singular for border (צ्) is translated by the plural Tà $8 \rho\llcorner\alpha$. Matthew writes

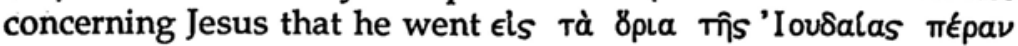

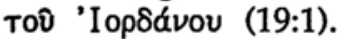

An examination of the statements in the Gospels leads us

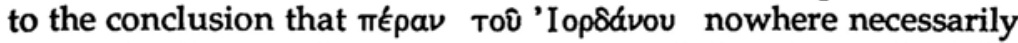
means the Peraea of Antipas, which extended to the south of the Decapolis, from Amathous to Machaerus. The evidence indicates rather the northern Trans-Jordan, and the reference in Matthew 19:1 to Joshua 19:34 (MT) could indicate the region of BashanBatanaea, for in both the Septuagint (Nu 32:32f.; Dt 3:8; 4:47) and Josephus (Ant. VIII.37) Bashan is designated explicitly as $\pi \epsilon \rho a v$

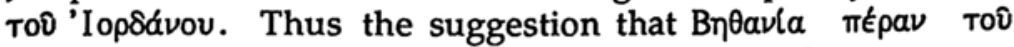
'Iop§ávou in John 1:28 means the region of Batanaea becomes even more worthy of consideration.

\section{BETHANY THE SAME AS BATANAEA?}

\section{The Philological Possibility}

From the Greek forms of Batanaea which Josephus uses, ${ }^{120}$ Batavta, Batavala and Batavela, there is no major difficulty in equating the area designated by the name with the Bntavla of John $1: 28,{ }^{121}$ especially if one assumes that the Evangelist in composing his Gospel had a special interest in making the names of the two places, Bethany beyond the Jordan and Bethany near Jerusalem, as close to one another as possible. The variation between $\tau$ and $\theta$ is

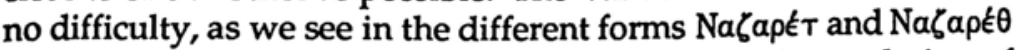
(e.g. Lk 4:16 v.l. ). Claude R. Conder appealed to the rendering of 109 in the Targums. ${ }^{12}$ This hint needs to be all the more carefully examined, since we see increasingly the importance of the Targums for the understanding of the Fourth Gospel. ${ }^{123}$ As it turns out, they give us various equivalents. Closest to the Johannine

120 Cf. A. Schalit, Namenwörterbuch zu Flavius Josephus. A Complete Concordance to Flavius Josephus (ed. K. H. Rengstorf), Suppl. I (Leiden, E. J. Brill 1968) $25 \mathrm{~b}$.

121 Cf. Eckhardt, Tod des Johannes 169.

12 PEFQS (1877) 185.

123 Cf. e.g. M. McNamara, Palestinian Targum and the New Testament (GNS 4; Wilmington, M. Glazier 1983) 234-41. For valuable assistance on this point I thank the Revd. Dr. Wolfgang Bittner (Fahrwangen / Switzerland). 
form of the name is the Jerusalem Targum. ${ }^{124}$ However, the definite form would be even closer to the usual designation בקית in the Jerusalem Talmud (j Maas IV 51b; j MS IV 54d).

\section{The Beginning of John the Baptist's Ministry}

Targum Neofiti I for Numbers $34: 15-16$ gives a very detailed description of the boundaries of Reuben, Gad and the half tribe of Manasseh, whose inheritance lay east of the Jordan. It is noteworthy that for making more precise the statements of the Masoretic text, not only the lists in Numbers 32:32-42 and Deuteronomy 3:1-17 but also the eschatological text Ezekiel 47, are referred to. ${ }^{125}$ The boundary lists in Neofiti I are older than those of the rabbinical literature; the list in Numbers 34:15-16 shows interesting connections with 1QGenAp 21:14-19, 126 where the land which Abraham was to receive for a possession is described. In connection with the successful campaign of Abraham against the four kings (Gn 14) the Genesis Apocryphon of Qumran exhibits a quite evident interest in the topography of the northern land east of the Jordan (1QGenAp 21:28-22:10). The pursuit of the kings goes 'as far as Helbon north of Damascus' (22:10). It would appear that the victory of the Father of Israel was understood in some parts of the Jewish tradition as a type of the victory which the Messiah would bring. ${ }^{12}$

Naphtali Wieder ${ }^{128}$ has brought forward noteworthy arguments that the migration of certain groups of the Essenes into the Iand of Damascus' ${ }^{\prime 29}$ was occasioned by their belief that the 124 Cf. J. Levy, Chaldaisches Wörterbuch über die Targumim . . . (ND Köln, J.
Melzer 1959) 119b.

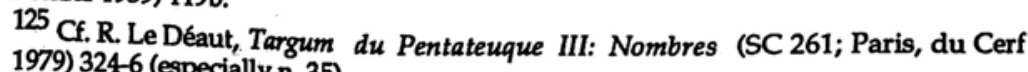
1979) 324-6 (especially n. 35).

$126 \mathrm{Cf}$. Le Déaut, Targum Nombres 318f. n.1.

127 Cf. N.
(1969) $86-8$.

128 The Judean Scrolls and Karaism (London, Horovitz 1962) 1-5.

129 The historicity of an Essene exodus into the area of Damascus is convincingly defended by S. Iwry, Was there a migration to Damascus? The problem of there' [Hebrew], EI 9'(1969) 80-8 and F. M. Strickert, 'Damascus Document VII, 1020 and Qumran Messianic Expectation', Reoue de Qumran 12 (1986) 327-49 (3347). Cf. also D. Dimant, 'Qumran Sectarian Literature', in M. E. Stone (ed.), Jewish Writings of the Second Temple Period (CRINT II/1; Assen, Van Gorcum 1984) 483-550 (494). 
messianic era would begin in the north. This interpretation becomes especially worthy of consideration when one reads the Damascus Document 7:12-21 in the light of the Karaite exegesis of the text of Amos 5:26-7, which also underlies the pesher of the Damascus Document. From such a real geographical background it would also be more intelligible why 'Lebanon' (alluding to Habakkuk 2:17) could become the designation by which the Essene community referred to itself (1QpHab12:3-4). Since Galilee, and, indeed, the north of the Holy Land generally, was regarded by Jewish Christianity as terra messianica, such traditions - as in similar cases - were afterwards suppressed in rabbinic Judaism. There are, however, traces of a messianic expectation directed towards the north. ${ }^{130}$ Thus, according to Leviticus Rabba 9 (111a) the Messiah appears in the north before he builds the Holy Place in the south. ${ }^{131}$ In Sifre Deuteronomium $41(79 b)$ it is presupposed that the return of Elijah is expected in the north. ${ }^{132}$ The verse from 1 Kings 19:15 referred to in this passage, namely, where God says to Elijah, 'Go, return on your way to the wilderness of Damascus,' could in Jewish exegetical thinking demand just such an understanding.

If one refers John 1:28 to the Batanaea region, then according to John 10:40 it was also the place (т6mos) 'where John at

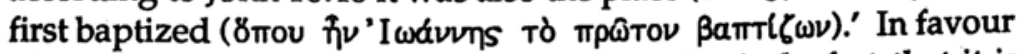
of our view of Bntavla as the name of a region is the fact that it is here denoted as a place ( $(6 \pi \%)$ ). John 11:30 illustrates extremely well how this word 'place' in the Fourth Gospel means an indefinite locality in contrast to a settlement: Bethany on the Mount of Olives is expressly named a village ( $\kappa \omega \mu \eta \eta)$, whereas the place, which is not defined more precisely, where Jesus was met by Martha is called a T6mos. This observation diminishes the difficulty that in John 1:28 the article is lacking that one should expect for a region. The conception of Bethany as the name of a region may further be the explanation why Origen, searching for a

130 Cf. Wieder, Judean Scrolls 10-12. In view of the evidence presented here, the critique of W. D. Davies, The Gospel and the Land. Early Christianity and Jewish Territorial Doctrine (Berkeley, University of California Press 1974) 222-35 has partly to be revised.

131 H. L. Strack - P. Billerbeck, Kommentar zum Neuen Testament aus Talmud und Midrasch I: Das Evangelium nach Matthäus (Munich, C. H. Beck 1926) $160 f$.

132 Strack - Billerbeck, Kommentar IV/2: Exkurse zu einzelnen Stellen des Neuen Testaments (Munich, C. H. Beck 1924) 789. 
settlement, found no place called Bethany on the east bank of the

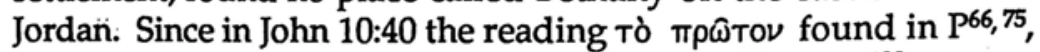

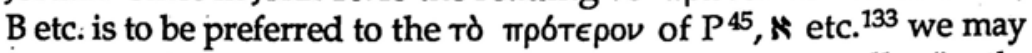
here say that the Baptist began his ministry generally in the Batanaea beyond the Jordan.' Especially if John viewed himself as the eschatological Elijah and his ministry was related to expectations similar to those of some Essenes, ${ }^{134}$ then the possibility cannot be excluded that he began his mission in the north as an acted sign of his role of heralding the Messiah.

\section{Jesus in the Northeast}

Apart from the passages we have already disussed (Jn 1:28, Mt 19:10//Jn 10:40), have we any other indications that Jesus stayed in the region of Batanaea? If one wishes to extract a geographical meaning from the route of Jesus' journey enumerated in Mark 7:31 ("Then he returned from the region of Tyre and went through Sidon to the Sea of Galilee, through [ávà $\mu \epsilon \sigma o \nu]$ the region of the Decapolis'), Jesus must also have passed through the Batanaean region. ${ }^{135}$ Friedrich $G$. Lang has penetratingly demonstrated that such a route, seen from the usual ancient highways, was by no means impossible, but also drew attention to the redactional character of the verse. ${ }^{136}$ According to the views outlined here one will still have to hold open the possibility that behind this redactional statement there could still be accurate knowledge. ${ }^{137}$

Naphtali Wieder ${ }^{138}$ and especially George W. E. Nickelsburg ${ }^{139}$ have pointed out that in the Enoch tradition and in the Testament of Levi the region around Mount Hermon appears as a prominent place for the reception of revelation. Enoch begins 133 Cf. T. Zahn, Das Evangelium des Johannes (KNT 4: Leipzig, A. Deichert
5/61921) 472 .

$134 \mathrm{Cf}$. R. Riesner, Jesus als Lehrer. Eine Untersuchung zum Ursprung des Evangelien-Überlieferung (WUNT II/7; Tübingen, J. C. B. Mohr ${ }^{3} 1987$ ) 292f. (with
bibliography). 135 Cf. F. Hauck, Das Evangelium des Markus (ThHK II; Leipzig, A. Deichert
1931) 95 .

136 "UJber Sidon mitten ins Gebiet der Dekapolis." Geographie und Theologie in Markus 7,31', ZDPV 94 (1978) 145-60. 137 Cf. also W. L. Lane, The Gospel of Mark (London, Marshall, Morgan \& Scott
1974) 265.

138 IJS 30 (1969) 88 n.11. 139 Enoch, Levi, and Peter: Recipients of Revelation in Upper Galilee', JBL 100
(1981) 575-600 (582-90). 
his ascent into heaven 'by the waters of Dan in the land of Dan, which lies southwestwards from Hermon' (1 Enoch 13:7). After he had woken from his visionary sleep, he encountered the

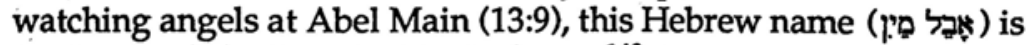
the basis of the later Ethiopic forms. ${ }^{140}$ The question concerns Abel Bet Maacha which is seven $\mathrm{km}$ west northwestwards of Tel Dan (2 Sam 20:14-15; cf. 1 Ch 16:4). According to the text of 1 Enoch 13:8 found in Qumran (4QEn'), Enoch saw in his vision 'the gates (of the heavenly temple). ${ }^{141}$ That reminds us, as does the sleep of Enoch, of the ascending and descending of the angels in Jacob's dream at Bethel (Gn 28:12-13). ${ }^{142}$ Nickelsburg accepts that the traditions behind 1 Enoch 12-16 were originally formed in Upper Galilee. ${ }^{143}$ The Testament of Levi gives us an account of a vision in many respects parallel to that of Enoch. This son of Jacob, who, according to Testamentum Levi 18, is a prototype of the messianic High Priest, ${ }^{144}$ is pasturing his herds at Abel Main (TLev 2:3; =4Q 213 1.13), sleeps in, is taken in a vision to Mount Hermon, which in the Greek text (TLev 2:5) is called boos $i \psi m \lambda 6 s^{145}$ The heavens open and angels (2:6) accompany him to the gates of Heaven (5:1).

Nickelsburg works out the parallels between the Enoch and Levi traditions to provide a setting for Peter's confession in Matthew 16:13-19, which according to his view goes back to a preMatthean tradition. ${ }^{146}$ The divine revelation to Peter which is presupposed in Matthew (16:17) is closely connected with the town of Caesarea Philippi (16:13) which is three and a half kilometres from Dan. Nickelsburg ${ }^{147}$ also briefly points to a possible connection of the Jewish texts to the transfiguration of

140 Cf. J. T. Milik, 'Le Testament de Lévi en Araméen', RB 62 (1955) 398-406 (4035). On the Ethiopic text see E. Isaac, in J. H. Charlesworth, The Old Testament Pseudepigrapha I: Apocalyptic Literature and Testaments (New York, Doubleday 1983) 20.

141 J. T. Milik (and M. Black), The Books of Enoch. Aramaic Fragments of Qumran Cave 4 (Oxford, Clarendon 1976) 193.

142 Cf. G. W. E. Nickelsburg, JBL 100 (1981) 584.

143 Nickelsburg, art. cit. 586.

144 Cf. Riesner, Jesus als Lehrer 313f.

145 M. de Jonge, The Testaments of the Twelve Patriarchs (PsVTGr I/2; Leiden, E. J. Brill 1978), 25f.; K. Beyer, Die aramäischen Texte 194.

146 JBL 100 (1981) 590-600.

147 Art. cit. 599. 
Jesus, which the first two Evangelists denote with the phrase 8 pos i $\psi m \lambda$ ós (Mt 17:1 // Mk 9:2) as taking place in the Hermon region

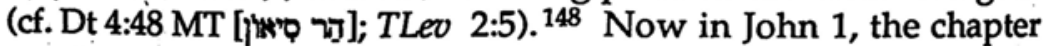
we have been investigating, we find not only a possible reminiscence of the confession of Peter in 1:42 (see Section IV.3) but also the words of Jesus in 1:51: 'Truly, truly, I say to you, you will see heaven opened, and the angels of God ascending and descending upon the Son of Man.' Here then we have a strong connection with the vision of Jacob, ${ }^{149}$ and also with the traditions of Enoch and Levi mentioned above. That can be additional evidence for our thesis that for the Fourth Evangelist the events portrayed in John 1 took place in the north.

\section{CONSEQUENCES AND QUESTIONS}

\section{A Real Topographical Name}

According to our interpretation John 1:28 fits well into the list of place names given by the Fourth Evangelist because it becomes clear that we are not dealing with a fictitious place which owes its existence to a purely symbolic interpretation or to sheer ignorance of local geography. When we understand $B \eta \theta a v i a$ here as the name of a region not of a town, the presupposition vanishes for Rudolf Bultmann's claim, 'that the place is mentioned because at the time of the Evangelist it was the home of a Christian congregation which had gone over from the Baptist to Jesus.' ${ }^{150}$ Nor need we trouble to search for the "'fig-tree of Nathaniel" in the midst of a Christian church of the Jordan area at the time of the composition of the Fourth Gospel' - a supposition so confidently accepted by Karl Kundsin. ${ }^{151}$ Before such remote aetiological explanations are grasped at the question should be seriously weighed as to whether the pre-Easter history of Jesus may not also be reflected in John 1 . If the Evangelist in 1:28 made a concrete statement about topographical detail, then he can have done so with the theological intention which Gottlob Spörri expressed in the words: 'the incarnation is also confirmed through

148 C. Wieder, Judean Scrolls 16.

149

C. S. Kim, The 'Son of Man' as the Son of God (WUNT I/30; Tübingen, J. C. B. Mohr 1983) 82-6.

150 John 94 end of $\mathrm{n} .3$ from 93.

151 Topologische Überlieferungsstoffe 21. 
such a spatial fixation of events'. ${ }^{152}$ This, nevertheless, does not exclude the possibility, which is yet to be shown (Section VII.4), that at the same time John ascribed a deep symbolical significance to the name.

\section{Baptist Groups and Jewish Christianity}

The region south of Damascus, which John 1:28 refers to, was of great significance both for the history of Judaism as well as for the early history of the church. The country of Batanaea represented a connection between the Babylonian Diaspora and the Jewish motherland. Here Herod the Great settled Jews from Babylon in order to protect the Pilgrim Way, a precaution which drew pious Jews from everywhere (Ant. XVII.23-7). ${ }^{153}$ Also, groups which stood on the fringe of Judaism's main-stream, or over against it, were represented in this region. In addition to the Essenes in the 'land of Damascus'(see Section VI.2) and the circles close to the Essenes in the region of Mount Hermon in which the Enoch and Levi traditions arose (Section VI.3), there were, according to our interpretation of John 1:28; 10:40-2, also disciples of John the Baptist. If, with Naphtali Wieder, we accept that in the Karaite literature an older apocalyptic tradition has been preserved, then for some Jews the land south of Damascus was requested as the assembling-place of the exiles before their eschatological return into the Holy Land. ${ }^{154}$ Is it just chance that in the closer context of John 10:40-2 the Evangelist declares (11:52) that Jesus should 'gather into one the children of God who are scattered abroad' ("va

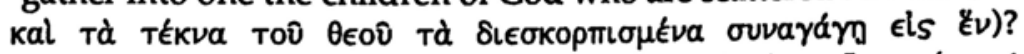
The 'sheep that are not of this fold' (10:16) and whom Jesus. 'must

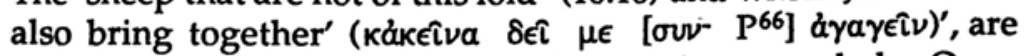
interpreted by a number of scholars, as for example by Oscar Cullmann, ${ }^{155}$ as referring to associated Jewish fringe-groups.

One branch of research accepts that the original homeland of the Mandaeans lay in southern Syria. ${ }^{156}$ In fact, it would not be

152 Das Evangelium nach Johannes I (Kap. 1-11) (Zürich, Zwingli V. 1950) 25.

153 Cf. also B. Pixner, $R Q 11$ (1983) 358.

154 Judean Scrolls 7-9.

155 The Johannine Circle. Its place in Judaism, among the disciples of Jesus, and in early Christianity. A study in the origin of the Gospel of John (ET; London, SCM 1976) 16, 47.

156 C. J. Thomas, Le Mouvement Baptiste en Palestine et Syrie (150 av. J.-C.-300 ap. J.-C.) (Gembloux, J. Duculot 1935) 220-40; K. Rudolph, Die Mandäer I: 
surprising if this melting pot of Jewish fringe groups was not also receptive to the syncretism of later Gnosticism. There is here a wealth of religio-historical questions involved. Nevertheless, according to our results, those scholars seem on the right track, who see at least one life-setting of the Fourth Gospel in mission and polemics within such Jewish fringe-groups.

Into the fourth century at least Batanaea was an important region where Jewish Christians settled. ${ }^{157}$ Ernst Lohmeyer has gone so far as to suppose that even before the persecution following Stephen's death (cf. Acts 9:1-2) Galilean missionaries from the circle of Jesus' relatives had evangelized this area. ${ }^{158}$ According to the testimony of Epiphanius of Salamis ${ }^{159}$ the village of Kochaba in the extreme southwestern corner of Batanaea 160 formed a particularly strong centre of Jewish Christianity. There dwelt not only the orthodox Nazorites (Haer. 29:7), but also Ebionites (30:2) with their conspicuous tendencies towards the doctrines and practices of the Essenes. ${ }^{161}$ Another Kochaba, where, according to Eusebius, Ebionites likewise dwelt (Onom. 72:1), was situated fifteen kilometres southwest from Damascus. Whether one of these two Kochabas is identical with the centre of the Lord's relatives ( $\delta \epsilon \sigma \pi 6 \sigma v \nu \alpha$ ) mentioned by Julius Africanus in Eusebius (HE I.7.14) is difficult to say. From our study it seems interesting that in respect to the distances in John 11 (see Section IV.1) 'Bethany beyond the Jordan' in John 1:28 must mean the extreme south-western part of Batanaea.

\section{On the Origin of John's Gospel}

With a great deal of material relating to the historical background, Klaus Wengst attempted to demonstrate that the Fourth Gospel arose in Gaulanitis or in Batanaea in the time of Herod Agrippa II.

Prolegomena (Göttingen, Vandenhoeck \& Ruprecht 1960) 229f., 248-52. 157 Cf. H. J. Schoeps, Theologie und Geschichte des Judenchristentums (Tübingen,
J. C. B. Mohr 1949) 270-7.

158 Galiläa und Jerusalem 54f.

urchristlichen Mission (BEvTh 55 . Cf. also H. Kasting, Die Anfänge der 159

G. A. Koch, A Criticial Investigation ormation concerning the Judaeo-Christians see (Diss. Pennsylvania 1976).

${ }^{160}$ For the different places with the name Kochaba see B. Bagatti, 'Ricerche su alcuni antichi siti Giudeo-Cristiani', LA 11 (1960/61) 288-314 (288-300).

161 Cf. J. Daniélou, Les manuscripts de la mer Morte et les origines du christianisme (Paris, Éditions de l'Orante 21974) 114-17. 
To be sure, he finds that 'in this connection it is specially interesting that Brownlee locates "Bethany beyond the Jordan" ... on the east bank of the Jordan, north of the Sea of Galilee' ${ }^{162}$ but he makes no further use of this suggestion. Now it might appear that Wengst's thesis is supported by our own interpretation of John 1:28. His thesis is, however, burdened with certain historical difficulties. ${ }^{163}$ These considerations apart, nothing may be concluded from a single place name that occurs by itself, since such statements in John occur quite frequently. The weight of evidence still favours the origin of the Fourth Gospel in Ephesus, ${ }^{164}$ but there may have existed Syrian churches beyond Asia Minor which were closely associated with the Johannine circle. Such an interpretation would be supported if the Odes of Solomon, with their similarly conspicuous Essene and Johannine colouring, could be shown to have originated in southern Syria at the end of the first century AD.165 The interpretation of John 10:40-2 which we have emphasized is that in Batanaea beyond the Jordan many of the Baptist's disciples followed Jesus. A Johannine church in this area would therefore have a connection with the pre-Easter history of Jesus. ${ }^{166}$

In another respect our geographical interpretation of John 1:28 has clear relevance for the question of the origin of the Fourth Gospel. For a long time it has been deduced, on the basis of the considerable frequency of topographical names from Judaea and Jerusalem, that the tradition lying behind the Fourth Gospel originated in the south. ${ }^{167}$ In a study particularly important for

162 Bedrängte Gemeinde und verherrlichter Christus. Der historische Ort des Johannesevangeliums als Schlüssel zu seiner Interpretation (BThSt 5; NeukirchenVluyn, Neukirchener V. $\left.{ }^{2} 1983\right) 91$ n. 290.

163 Cf. G. Theissen, "Meer" und "See" in den Evangelien. Ein Beitrag zur Lokalkoloritforschung, SNTU 10 (1985) 5-25 (17).

164 Impressive evidence in support of this hypothesis was highlighted by Professor Martin Hengel in his November 1985 lecture in Heidelberg. Cf., provisionally, F. Neugebauer, Die Entstehung des Johanneseoangeliums (ATh I/36; Stuttgart, Calwer V. 1968), especially 20-4; S. S. Smalley, John - Evangelist and Interpreter (Exeter, Paternoster ${ }^{2}$ 1983) 68-74.

165 C. J. H. Charlesworth, 'Qumran, John and the Odes of Solomon', in id., John and Qumran 107-36 (135f.); more cautiously expressed by him in The Old Testament Pseudepigrapha II (New York, Doubleday 1985) 725f.: about AD 100 in the vicinity of Antioch.

166 Cf. also C. H. H. Scobie, Johannine Geography', StRel 11 (1982) 77-84.

167 So e.g. C. H. Dodd, Historical Traditions 244-7. 
the Johannine chronology Eugen Ruckstuhl expressed this opinion extremely clearly: In contrast to the Synoptic Gospels the Gospel of John is stamped strongly with the events in the south of Palestine and in the Jewish capital of Jerusalem. When in 21:24 "the disciple whom Jesus loved" (21:20) is mentioned as the main witness of this Gospel, we may accept that he above all was responsible for the special Johannine traditions connected with Jerusalem and its surrounding areas, which the Fourth Evangelist adopted and developed, often in the direction of his proclamation ... All these narratives, which go beyond those of the Synoptists, render it probable that the witnesses of "the disciple whom Jesus loved" presupposed that Jerusalem was his residence at that time. ${ }^{168}$ For this reason also 'the disciple whom Jesus loved' and whose calling, according to Ruckstuhl, is narrated in John 1:25-40, cannot be the Galilean fisherman, John the son of Zebedee. Alternatively, we may explain the preponderance of Judaean place names in the Fourth Gospel by saying that the Evangelist wanted to supplement the Synoptists with their major emphasis on Jesus' activity in Galilee. We should note further that the Fourth Evangelist possesses just as relatively detailed knowledge of places in Samaria (Jn 4) as well as Galilee (6:1-14), which was pointed out not least by Karl Kundsin. ${ }^{169}$ But above all we may say: whoever 'the disciple whom Jesus loved' was, according to our interpretation of John 1:28 he was called to be a disciple in the far north of the country, and this militates against his origin in Jerusalem.

\section{Topography and Theology}

John 10:42 is a typical Johannine transitional passage and certainly the most important. The beginning and the end of Jesus' ministry is connected through the name Bnoavia. In Bethany beyond the Jordan (In 1:28) the ministry of Jesus once more reaches a highpoint through the faith of many who believe in him (10:40-2). With the raising of Lazarus in Bethany near Jerusalem (11:1) Jesus performs his greatest 'sign', which at the same time finally brings him on the way of suffering (11:45-53). If at first it seems only a

168 Der Jünger, den Jesus liebte. Geschichtliche Umrisse', BiKi 40 (1985) 77-83 (78). R. H. Lightfoot, Locality and Doctrine in the Gospels (London, Hodder and Stoughton 1938) 147 could even write, It seems therefore that in St. John's gospel the disciples as a whole are regarded as resident in Judaea, not in Galilee'.

169 Topologische Überlieferungsstoffe 50. 
piece of semantic word-play that the Evangelist tries to equate the regional name Batanaea with the place name Bethany, this has in reality a deep theological significance. What began in the region specially marked out by the Jewish messianic hope (Batanaea) through the proclamation of John the Baptist (1:29: 'Behold the Lamb of God, who takes away the sin of the world'), finds its completion through the cross and resurrection of Jesus in Jerusalem, which events are already typified in the raising of Lazarus (at Bethany) in the nearest proximity to the Holy City. The events in the north and in the south, the beginning and the completion of salvation, cannot be separated. If in John 1:28 Batanaea is meant, then all four classical regions of the Jewish motherland - Galilee, Judaea, Samaria, and the land east of the Jordan - have a specially emphasized place in the Fourth Gospel. And so with the help of topography also the Evangelist makes it clear that the sending of Jesus is for the whole of Israel. ${ }^{170}$

170 Cf. W. A. Meeks, 'Galilee and Judea in the Fourth Gospel', JBL 85 (1966) 15969 (167f.) and also D. Mollat, 'Remarques sur le vocabulaire spatial du quatrième évangile', TU 73 (1959) 321-8. 